\title{
Metode Bermain Peran pada Materi Menjaga Keutuhan NKRI dalam Rangka Meningkatkan Hasil Belajar Siswa Kelas V SD
}

\section{Harismaliza}

\begin{abstract}
Abstrak
Penelitian ini dilatarbelakangi rendahnya hasil belajar siswa tentang Negara Kesatuan Republik Indonesia. Indikator yang ingin dicapai dalam pembelajaran adalah menanamkan sikap cinta tanah air.Di samping itu kurangnya motivasi siswa dalam pembelajaran PKn yang mereka anggap membosankanhasil belajarnya masih jauh di bawah KKM.Rumusan penelitian ini adalah bagaimanakah penerapan metode pembelajaran bermain peran untuk meningkatkan hasil belajar PKn tentang Negara Kesatuan Republik Indonesia di kelas V SD Negeri 08 Nan Sabaris? Penelitian ini merupakan penelitian tindakan kelas pada siswa kelas V di SDN08 Nan Sabaris. Penelitian ini dilakukan dalam dua siklus. Siklus I terdiri dari 3 kali pertemuan dan siklus II terdiri dari 2 kali pertemuan, setiap akhir siklus dilakukan penilaian evaluasi sebagi tindak lanjut dari tindakan yang dilakukan. Hasil penelitian menunjukkan bahwa dengan metode bermain peran dapat meningkatkan hasil belajar siswa dan dapat mengembangkan nilai-nilai pancasila dalam kehidupan siswa.
\end{abstract}

Kata kunci: metode bermain peran, hasil belajar dan mata pelajaran PKn

\section{PENDAHULUAN}

Pelajaran Pendidikan Kewarganegaraan (PKn) yang di pelajari di sekolah, dianggap ilmu yang sukar dan sulit dipahami. PKn merupakan mata pelajaran yang memfokuskan pada pembentukan diri yang beragam dari segi agama, sosio-kultural, bahasa, usia dan suku bangsa untuk menjadi warga negara yang cerdas, terampil dan berkarakter yang diamanatkan oleh Pancasila dan UUD 1945. Begitu luasnya materi PKn menyebabkab anak sulit untuk diajak berfikir kritis dan kreatif dalam menyikapi masalah yang berbeda. Sementara anak usia sekolah dasar tahap berfikir mereka masih belum formal, karena mereka baru berada pada tahap Operasional Konkret (Piaget: 1920). Hal yang dianggap logis, jelas dan dapat dipelajari bagi orang dewasa terkadang tidak dapat diterima dan membingungkan siswa.Akibatnya banyak siswa yang tidak memahami konsep materi PKn.

Penulis menemukan bahwa sebagian besar siswa kurang aktif sehingga kemampuan berfikir kritis tidak terasah dengan baik.Salah satunya dalam materi Negara Kesatuan Republik Indonesia (NKRI) pada mata pelajaran PKn. Apabila anak menghadapi masalah berbeda dengan yang dicontohkan, anak belum mampu berfikir kritis dan menemukan solusi masalah.Hal ini menyebabkan banyak anak yang kurang termotivasi dalam mempelajari PKn, sehingga rendahnya hasil belajar bahkan jauh dari KKM yang telah ditentukan.Nilai rata-rata siswa pada mata pelajaran PKN adalah 68. Hasil penilaian diketahui bahwa dari 25 orang siswa terdapat 8 orang $(32 \%)$ yang memperoleh nilai di atas 75 dan 17 orang (68\%) memperoleh nilai di bawah 75 .

Masalah ini cukup mengkhawatirkan sehingga penulis menawarkan solusi dengan menggunakan metode bermain peran pada materi Negara Kesatuan Republik Indonesia (NKRI).Bermain peran merupakan kegiatan yang mengeksplorasi hubungan antar manusia dengan cara memperagakan dan mendiskusikan sehingga orang dapat mengeksplor perasaan, sikap, nilai dan berbagai strategi pemecahan masalah (Endang: 2009).Pembelajaran dengan menggunakan metode bermain peran memberi kesempatan kepada siswa untuk merefleksikan apa yang sedang terjadi.Bermain peran dapat digunakan untuk melatih para siswa mengekspresikan masalah-masalah hubungan manusia dan mengembangkan kemampuan perasaan, sikap dan nilai.

Rumusan penelitian ini adalah Bagaimanakah penerapan metode pembelajaran bermain peran untuk meningkatkan hasil belajar PKn tentang Negara Kesatuan Republik Indonesia di kelas V SD Negeri 08 Nan 
Sabaris? Penelitian ini bertujuan meningkatkan hasil belajar siswa dengan menerapkan metode bermain peran pada materi NKRI mata pelajaran PKn.

\section{METODOLOGI PENELITIAN}

Penelitian ini menggunakan metode penelitian tindakan kelas.Menurut Wardhani (2008) PTK dilakukan oleh guru di dalam kelasnya sendiri melalui refleksi diri, dengan tujuan untuk memperbaiki kinerjanya sebagai seorang guru, sehingga hasil belajar peserta didik meningkat.Penelitian ini dilaksanakan di SD Negeri 08 Nan Sabaris. Subjek penelitian adalah siswa kelas V semester I. Penelitian ini dilakukan dalam dua siklus, pada siklus I terdiri dari 3 kali pertemuan dan pada siklus II dilakukan 2 kali pertemuan, setiap akhir pertemuan dilakukan evaluasi penilaian pembelajaran. Siklus penelitian tindakan kelas ini dimulai dengan membuat perencanaan, melaksanakan, mengamati, dan melakukan refleksi.

Perencanaan merupakan kegiatan yang dilakukan peneliti membuat perencanaan kegiatan pembelajaran.Pada kegiatan perencanaan, peneliti juga mempersiapkan evaluasi dan media yang digunakan.Pelaksanaan pembelajaran dilakukan dengan menggunakan metode bermain peran.Siswa diminta memainkan peran dalam memilih ketua kelas.Hal ini membantu siswa memahami tentang penerapan demokrasi. Selama proses pembelajaran berlangsung dilakukan pengamatan. Pengamatan untuk melihat keaktifan siswa dalam belajar.Setelah itu dilakukan refleksi.

\section{HASIL DAN PEMBAHASAN PENELITIAN Hasil Penelitian}

Hasil penelitian yang dilakukan pada siswa kelas V SD Negeri 08 Nan Sabaris tentang materi Negara Kesatuan Republik Indonesia melalui metode bermain peran yang dilaksanakan pada siklus I dan siklus II seperti yang dijabarkan sebagai berikut :

\section{Pra Siklus}

Penelitian yang dilakukan pada pra siklus terhadap mata pelajaran PKn kelas V semester I di SD Negeri 08 Nan Sabaris, tahun pelajaran 2015 / 2016 dengan materi pokok Negara Kesatuan Republik Indonesia dilaksanakan pada hari Kamis, 08 Oktober 2015 hasilnya belum memuaskan, yaitu hanya rata-rata $68 \%$ atau hanya 8 siswa yang tuntas sementara 17 siswa belum tuntas.

\section{Pelaksanaan}

Pelaksanaan penelitian tindakan kelas pada pra siklus dilaksanakan pada hari Rabu, tanggal 30 September 2015.Pelaksanaan pembelajaran dilaksanakan sesuai dengan rencana kegiatan yang telah disusun.

\section{Pengamatan}

Dari hasil pengamatan diketahui bahwa siswa belum aktif dalam pembelajaran.Pada saat diskusi kelompok, siswa.Saat diberi penjelasan oleh guru ada siswa yang bermain sendiri.Sedangkan hasil pengamatan terhadap guru diketahui guru kurang menguasai materi, guru belum bisa mengontrol keaktifan siswa sewaktu berperan. Selain itu, guru belum menggunakan alat peraga sehingga siswa kurang memperoleh hasil yang memuaskan.

\section{Refleksi}

Hasil refleksi yang dilakukan antara peneliti dan observer diperoleh beberapa kelemahan selama proses pembelajaran. Kelemahan tersebut adalah sebelum pelajaran dimulai guru tidak mengkondisikan siswa untuk menerima pelajaran, sehingga mereka belum memiliki kesiapan dalam belajar.Pada waktu pemberian materi guru hanya ceramah, sehingga siswa hanya menggambarkan materi NKRI itu seperti apa. Dari refleksi itu guru menyadari kekurangannya dalam proses pembelajaran oleh karena itu guru akan memperbaikinya pada siklus berikutnya.

\section{Siklus I}

Penelitian tindakan kelas siklus I dilaksanakan pada hari Kamis tanggal 15 Oktober 2015. Dengan dibantu oleh teman sejawat yang bertindak sebagai observer, peneliti melaksanakan sesuai rencana. Skenario pembelajaran berlangsung dengan baik.Peneliti melaksanakan sesuai rencana.Pada akhir pembelajaran peneliti mengadakan evaluasi hasil belajar untuk mengetahui tingkat keberhasilan. Hasil penelitian tindakan kelas pada siklus I hanya mencapai nilai keberhasilan rata-rata kelas 68,20. Berarti masih dibawah KKM dan harus dilanjutkan pada kegiatan siklus II

\section{Pelaksanaan}

Pelaksanaan tindakan kelas pada siklus I dilaksanakan pada hari Kamis, tanggal 15, 22 dan 29 Oktober 2015 dikelas V. Kegiatan belajar mengajar sesuai dengan apa yang tertulis dalam rencana pelaksanaan pembelajaran. 


\section{Pengamatan}

Pada tahap ini pengamat mencatat apa yang telah terjadi pada pelaksanaan pembelajaran dikelas dengan menggunakan lembar observasi. Hasil pengamatan diketahuibahwa :

- Penjelasan materi sangat cepat sehingga kurang dipahami siswa

- Kurang memberikan kesempatan pada anak untuk bertanya

3. Refleksi

Hasil tes formatif, menunjukkan adanya peningkatan pelaksanaan pembelajaran dibandingkan dengan pembelajaran sebelumnya.Ketuntasan pembelajaran belum mencapai ketuntasan 75\%.Maka peneliti mengadakan penelitian tindakan kelas kembali dengan memperbaiki kekurangan yang terdapat pada siklus I.

\section{Siklus II}

Kegiatan penelitian tindakan kelas pada siklus II dilaksanakan pada hari Kamis, tanggal 05 November 2015, peneliti melaksanakan sesuai rencana.Skenario pembelajaran berlangsung dengan baik.Pada akhir pembelajaran peneliti mengadakan evaluasi hasil belajar untuk mengetahui tingkat keberhasilan.

\section{Pelaksanaan}

Pelaksanaan penelitian tindakan kelas padasiklus II pada hari Kamis, tanggal 05 dan 12 November 2015 bertempat di SD Negeri 08 Nan Sabaris.

\section{Pengamatan}

Hasil pengamatan dari observer selama proses pembelajaran siklus II diketahui bahwa siswa memperhatikan penjelasan yang diberikan oleh guru dengan baik. Siswa sudah berpartisipasi dalam kegiatan pembelajaran, sudah ada keinginan untuk mencari penyelesaian permasalahan.Siswa sudah mulai mau bertanya jika ada kesulitan, dan mulai berani untuk memerankan tokoh yang diberikan.Sedang pengamatan yang diperoleh observer kepada guru yang mengajar adalah guru sudah mempersiapkan rencana pembelajaran dengan baik, metode yang digunakan sudah tepat, pemberian motivasi sudah cukup baik.

\section{Refleksi}

Setelah melakukan beberapa tindakan yaitu penelitian tingakan kelas pra siklus, siklus I dan siklus II.Dari hasil refleksi yang dilakukan tersebut teman sejawat selaku observer juga menemukan beberapa hal, diantaranya :Hasil evaluasi belajar siswa meningkat, sebagian besar siswa sudah memahami materi, siswa sudah berani maju tampil memerankan tokoh yang diperankannya, serta siswa sudah berani untuk mengajukan pertanyaan.

\section{Pembahasan}

Metode bermain peran membuktikan dapat meningkatkan hasil belajar siswa.Metode bermain peran membantu siswa berperan atau memainkan peranan dalam dramatisir masalah social atau psikologis.Bermain peran di gunakan untuk menjelaskan perasaan, sikap, tingkah laku, dan nilai, dengan tujuan untuk menghayati perasaan, sudut pandang dan cara berfikir orang lain (Depdikbud, 1964 : 171 ).Melalui bermain peran, para siswa mencoba mengeksploitasi masalah - masalah hubungan antara manusia dengan cara memperagakannya. Hasilnya didiskusikan dalam kelas.Proses belajar dengan menggunakan metode bermain peran diharapkan siswa mampu menghayati tokoh yang dikehendaki, keberhasilan siswa dalam menghayati peran itu akan menentukan apakah proses pemahaman, penghargaan dan identifikasi diri terhadap nilai berkembang (Hasan, $1996: 266$ ).

Metode bermain peran dapat membantu siswa mengembangkan nilai-nilai karakter yang terdapat dalam mata pelajaran PKn khususnya materi Negara Kesatuan Republik Indonesia.Dengan demikian fungsi pembelajaran PKn tidak hanya sekadar memberi pengetahuan tentang pendidikan kewarganegaraan saja, tetapi juga pembentukan karakter yang sesuai dengan pancasila.Menurut hasil penelitian Cogan (1998), ada delapan karakter yang dapat dibentuk melalui belajar PKn yaitu sebagai berikut: (1) Kemampuan mengenal dan mendekati masalah sebagai warga masyarakat di sekitar. (2) Kemampuan bekerjasama dengan orang lain dan memikul tanggungjawab atas peran atau kewajibannya dalam masyarakat. (3) Kemampuan untuk memahami, menerima, dan menghormati perbedaan - perbedaan pendapat. (4) Kemampuan berfikir kritis dan sistematis. (5) Kemampuan menyelesaikan konflik dengan cara damai tanpa kekerasan. (6) Memiliki kemampuan untuk bergaya hidup sederhana. (7) Memiliki kepekaan terhadap lingkungan dan mempertahankan hak - haknya dalam masyarakat. (8) Memiliki kemauan dan kemampuan untuk berpartisipasi dalam kehidupan bermasyarakat. 


\section{KESIMPULAN DAN SARAN}

\section{Kesimpulan}

1. Metode bermain peran dapat meningkatkan hasil belajar siswa dan mengembangkan nilai-nilai pancasila dalam diri siswa.

2. Prosentase ketuntasan belajar siswa mengalami peningkatan yang signifikan setelah menggunakan nmetode bermain peran.

\section{Saran}

1. Guru harus memberi motivasi dan bimbingan pada siswa yang mengalami kesulitan.

2. Guru hendaknya menciptakan suasana belajar yang menyenangkan.

3. Di era kompetisi siswa perlu dilatih untuk berani berperan aktif dalam scenario yang telah disusun, mengemukakan pendapat oleh karena itu latihan membimbing kawan - kawannya dalam melakukan bermain peran merupakan ajang latihan yang cukup kreatif.

Siswa perlu dilatih untuk bergaul dan bekerjasama yang harmonis dalam kelompoknya dengan kegiatan yang positif. Oleh karena itu bekerja dalam kelompok untuk menyelesaikan tugas tertentu merupakan cara yang efektif untuk melatih sifat social pada siswa.

\section{DAFTAR PUSTAKA}

Andayani, dkk.2010, Pemantapan Kemampuan Profesional. Jakarta, Universitas Terbuka.

Aswani, Zaenul,2004, Tes dan Asesmen di SD, Jakarta, Universitas Terbuka.

Denny, Setyawan, 2005, Komputer dan Media Pembelajaran, Jakarta, Universitas Terbuka.

Endang Komara. 2009. Metode Bermain Peran. Ainamulyana.blogspot.co.id. Akses tanggal 6 september 2016

Gatot, Muhsetyo, Drs. M.Sc, dkk, 2007, Pembelajaran PKN, Jakarta, Universitas Terbuka.

Mulyani Sumantri, Nana Syaodih. 2007. Perkembangan Peserta Didik. Jakarta, Universitas Terbuka.

Samsudin, Abin, 2004, Profesi Keguruan 2, Jakarta, Universitas Terbuka.

Suciati, Drs. Dkk, 2004, Belajar dan Pembelajaran 2, Jakarta, universitas Terbuka.

Wardani, I.G.A.K, 2008, Penelitian Tindakan Kelas, Jakarta, Universitas Terbuka.

Wahyudi Duin, Supaiyati, Ishak, Abduhak, 2001, Pengantar Pendidikan, Jakarta, Universitas Terbuka.

Dra. Dyah Sriwilujeng, M.Pd, Buku PKn untuk SD Kelas V, Jakarta, Esis.

Pranaja S dkk, Buku Fokus PKn untuk SD Kelas V, Jakarta, Sindutama. 